\title{
Fungal Keratitis
}

National Cancer Institute

\section{Source}

National Cancer Institute. Fungal Keratitis. NCI Thesaurus. Code C128370.

Keratitis caused by fung i. 